\title{
Civic Education, Democracy and the English Political Tradition ${ }^{1}$
}

\author{
WILFRED CARR \\ University of Sheffield \\ ANTHONY HARTNETT \\ University of Liverpool
}

\begin{abstract}
SUMMARY.-En este artículo se aborda el problema de la educación cívica desde el punto de vista del Modelo de Democracia Moral y de Democracia de Mercado, ya que ambos entiende de forma distinta la 'educación del ciudadano'. Se hace un breve recorrido histórico por el sistema educativo del Reino Unido y se analizan las causas de la preeminencia del modelo de mercado en la sociedad británica y sus repercusiones en la escuela. Los autores defienden un concepto de ciudadano más social y menos individualista siguiendo el prototipo de la Antigua Grecia.
\end{abstract}

\begin{abstract}
'The powerful still do not favour the cultivation among the lower orders of the scepticism and critical intelligence that is valued among their betters... The decline in investment and support for public education in this country at the moment is... a vindictive rather than a prudent economy. At stake is more than a hundred years of adventure beyond the mere basics, a span in which schools... have tried to make people independent thinkers capable of participation in the democratic process and of deciding what the future of their own society shall be like... We must now find ways of ensuring that a defensive, and more apprehensive, establishment in the context of a contracting economy does not make a critical education an education reserved for privilege'. [Lawrence Sthenhouse, 1982] ${ }^{2}$
\end{abstract}

\section{INTRODUCTION}

The National Curriculum, like many of the educational reforms in England since 1979, has altered and restructured the entire framework within which educational debate takes place. For teachers and other involved in education, it has snuffed out the energy and space in which to develop serious alternatives, by enabling the New Right to capture the key educational concepts of 'quality', 'standards', 'discipline', 'testing' and 'achie-

1. The issues and themes of this essay are discussed in more detail in: Carr, W. \& Hartnett, A. (1994), Democracy and the Struggle for Education (Cassells).

2. Quoted in Plaskow, M. (ed), The Life and Death of the Schools Council (Falmer Press, 1985). 
vement'. Even the recent effective opposition to an elaborate and byzantine stystem of assessment is likely to lead to a greater concentration on 'basics' and to more traditional pencil and paper tests, both of which the New Right wanted from the start.

These characteristics of debate about the National Curriculum raise a wider issue about how educational debate has developed since the mid-1970's. During this period, educational debate has become atomised and de-contextualised so that issues such as 'citizenship' are talked about as if they existed in a social, political and historical vacuum. What passes for serious debate about the nature and purpose of education for citizenship does so as if issues of power, status and wealth could be disregarded; as if politics, ideology and institutional traditions were not important; and as if wider issues concerning such central notions as democracy, justice, equality, and freedom could be ignored. It seems to be assumed that, 'citizenship' can be plucked out of the air and talked about as if England in the 1990's was already a fully developed democratic society: almost a delightful 'Eden, a demi-paradise... set in... a silver sea' : a nice mixture of classical Greece, medieval solidarity, Victorian respectability, and modern industrial affluence. But, of course, it is none of these things, and any educational debate which assumes that this is how things are, is bound to fail to grapple with the complexities of English education at the end of the 20th century. In this essay we take citizenship as an issue and use it to illuminate the quality and characteristics of educational and political discussion and debate. To do this we first connect citizenship to wider issues in political and social theory. Secondly, we locate views about citizenship within the English political and educational traditions.

\section{CITIZENSHIP, POLITICS AND DEMOCRACY}

'Citizenship' and 'citizens' are distinctively 'un-English' and have the smell of the continent about them. The English traditionally talk about being loyal subjects of the Queen ${ }^{3}$. However, recently, and relatively suddenly, the word 'citizenship' has been constantly on the lips of politicians, academics and educators from both the New Right and the New Left. Hugo Young, writing in the Guardian a few years ago explained this situation in the follow way:

Something is rotten in the state of Britain, and all the parties know it... The buzz word emerging as the salve for this disease is something called 'citizenship'...

Somewhere out there is an immense unsatisfied demand for it to mean something. But it needs to become much more than a word ${ }^{4}$.

Explanations of 'what is rotten' in Britain, and hence of the 'disease' for which citizenship is prescribed as the cure, have varied. For some, the call for citizenship is a belated response to the steady drift towards narrow individualism. For others, it is a reaction to the dismantling of the welfare state, the erosion of local democracy and the increasing power of the state. But whatever the reasons for putting citizenship on the

3. Johnson, R. W., The Politics of Recession (Macmillan 1985), p. 231.

4. Young, H., "Citizen" The catch-all rallying cry' (Guardian, 1 September 1988). 
political and educational agenda, the demand for it to 'mean something' remains unsatisfied. 'It needs', in Hugo Young's words, 'to become much more than a word' particularly if we are to begin to think about education for citizenship and about the kind of curriculum provision this entails.

Discovering what the concept of citizenship actually means is more difficult than it sounds. The reason why this is so is that citizenship is a paradigmatic example of an 'essentially contested concept' - a concept whose very meaning is itself the subject of intense controversy and conflict between rival social and political groups ${ }^{5}$. Citizenship is a 'contested' concept in the sense that the criteria governing its proper use are constantly challenged and disputed; such disputes are 'essential' in the sense that arguments about these criteria turn on fundamental political issues for which a final rational solution is not available. To concede that citizenship is a political concept whose meaning has always been, and still is, 'essentially contested' is not to say that the concept is so elastic that it can mean whatever anybody wants it to mean. Contested concepts always have some uncontested common core which provides an understanding of the general ideas they express and helps to clarify the substantial points of disagreement that rival and conflicting interpretations of its meaning incorporate.

One way of identifying the common core of any essentially contested concept is to look to its history. As with so much else, the origines of the concept of citizenship are to be found in Athenian democracy so that its current meaning must, however, tenuously, be connected to the meaning it had in ancient Greece. In the earliest systematic analysis of the concept, Aristotle defines a citizen as 'someone who participates in public affairs! $!^{6}$ Although in the Athenian polis the right to participate in public affairs was restricted to a small minority of the general population, citizenship nevertheless marked the emergence of the idea that man (but not woman) was 'a political animal' who could adequately fulfil himself only by sharing in the common life of a political community. For Aristotle man was, by nature, homo politicus whose very being was constituted and affirmed through political activity. Citizens did not understand themselves as private individuals with certain legal rights but as free and equal participants in a political order developing and realising their human capacities by making and obeying laws within the framework of a common life and on the basis of the common good.

The story of the eclipse of the Greek ideal of citizenship is no doubt very complex and very difficult to tell ${ }^{7}$. It will, in part, require some explanation of why, in modern western democracies, the role of the citizen has been transformed by a division of labour between an 'active' political elite of full-time rulers, and a 'passive' political majority who only participate in politics by casting votes in periodic elections. But what such a story will also reveal is how the history of the concept of citizenship is a history of social struggle and political conflict in which, and through which, its original Greek meaning has been gradually changed. These changes are analysed in some detail by T. H. Marshall who is now generally regarded as offering the most authoritative formulation of the

5. Gallie, W. R., Esentially Contested Concepts (Proceedings of the Aristotelian Society, 1955-56), pp. 167-98.

6. Aristotle, Politics (Harmondsworth, Penguin, 1981), p. 19.

7. Heater, D., Citizenship: The Civic Ideal in World History, Politics and Education (London, Longman, 1990). 
meaning of citizenship in modern industrial democracies. His definition of citizenship is worth quoting at length:

'Citizenship is a status bestowed on all those who are full members of a community. all who possess the status are equal with respect to the rights and duties with which the status is endowed. There are not universal principles that determine what those rights and duties shall be, but societies in which citizenship is a developing institution create an image of ideal citizenship against which achievement can be directed. The urge forward along the path thus plotted is an urge toward a fuller measure of equality, an enrichment of the stuff of which the status is made, an increase in the number of those upon whom the status is bestowed... Citizenship requires a direct sense of community membership based on loyalty to a civilisation which is a common possession. It is a loyalty of free men endowed with rights and protected by a common law. It's growth is stimulated by the struggle to win those rights and their enjoyment when won ${ }^{8}$.

The obvious attraction of Marshall's definition is that it makes 'membership of a community', 'rights' and 'duties' definitive features of citizenship without stipulating how 'membership' is to be determined or what the specific rights and duties of citizens should be. Who are to be 'full members of the community'? Who are to be excluded? What kind of rights should citizens have? Is participation in the exercise of political power a right or a duty? Are the duties of citizenship absolute? It is the different and often conflicting ways in which these questions are asked and answered that give rise to rival and incompatible account of what citizenship actually means.

What Marshall's definition also recognises is that these questions cannot be answered by appealing to any absolute standards. Rather, our sense of what the appropriate rights and duties of citizenship should be, is always changing and evolving under the impetus to make available to all a status previously limited to a privileged elite. Our present understanding of citizenship is thus the result of past struggles and organised protests (such as those of the Chartists and the Suffragettes) on behalf of social groups who were denied a full degree of legal, social and political equality. In this sense, citizenship is the dynamic historical process of social transformation through which the demand for great social justice and a more egalitarian social order has been gradually promoted and realised.

For Marshall the three key stages in this historical process has been the sequential evolution of civil, political and social rights over the past 250 years. Civil rights refer primarily to those legal rights -such as the freedom to own property and freedom and justice before the law- which were established for some groups by the end of the eighteenth century. Political rights -particularly the right to vote- were extended in the nineteenth and twentieth centuries. Social rights -such as the right to a minimum level of health care and economic security- were finally conceded in the post-war establishment of the Welfare State.

For Marshall, the modern concept of citizenship is counter-posed to social class and the civil, political and social rights that have emerged have served both to modify 'the worst defects of economic inequality' and to make 'modern capitalist system and liberal

8. Marshall, T. H., Citizenship and Social Class and Other Essays (Cambridge, Cambridge University Press, 1950), p. 2. 
polity more equal and just, without revolutionary activity'. Marshall was also aware of the connections between these rights: of how, for example, the extension of the political right to vote led to improved civil rights for trade unionists, which in turn led to better social rights for ordinary workers. He, also, highlighted the fragile and contingent nature of these hard won rights and of the central role of political struggle in their achievement. For Marshall, citizenship rights were always the outcome of '...struggle against hierarchy in its traditional feudal form, struggle against inequality in the market-place, and struggle against social injustice perpetuated by state institutions. Rights had to be fought for, and when they were won they had to be protected. At the root of these processes was (and is) the delicate balance between social and political forces ${ }^{10}$.

Because Marshall's account of the development of citizenship has achieved such authoritative status, it is unsurprising to note that in the National Curriculum Council's recent guidelines on education for citizenship are influenced by both his definition of citizenship and his formulation of civil, political and social rights. What is suprising is that, in the document containing these guidelines, social rights are virtually ignored and no reference is made to the Welfare State at $\mathrm{all}^{11}$. Even more remarkable is the fact that the document repeatedly refers to "the responsabilities and rights of citizens in a democratic society' without ever clearly explaining what these responsibilities and rights are, or how the notion of the democratic citizen is to be understood. Yet in the absence of some such explanation, the key terms used in the document -terms such as 'participation' and 'democracy'- remain vacuous. Although the document declares that the 'the aim of education for citizenship is to establish the importance of positive participative citizenship, ${ }^{12}$ its reluctance to address unavoidable political questions about the participative role of citizens in a democracy means that the guidance given to schools remains ambiguous and unclear.

That these questions are both unavoidable and political stems from the fact that the 'liberal democracy' of the United Kingdom is an amalgamation of both 'liberalism' and 'democracy' -two political traditions which, because they are based on different political values, give rise to internal tensions about how the concepts of democracy and citizenship are to be understood ${ }^{13}$. It is a commonplace for political theorists to explain these tensions by constructing analytical 'models' which encapsulate the core principles, key features and basic assumptions which different ideas and arguments about democracy tacitly presuppose ${ }^{14}$. One of these models -the 'moral' model of democracy- is intended to accommodate a broad range of democratic theories ranging from the "classical' theory of ancient Greece to the 'direct democracy' of Rousseau ${ }^{15}$ and the 'developmental' democracy of J. S. Mill ${ }^{16}$. It also includes the more modern 'participatory'

9. Held, D., Political Theory and the Modern State (Polity Press 1989), 190.

10. Ibid., pp. 193-94.

11. Curriculum Guidance 8: Education For Citizenship (The National Curriculum Council, 1990).

12. ibid., p. 2.

13. MacPherson, C. B., The Life and Times of Liberal Democracy (Oxford, Oxford University Press, 1977).

14. For a recent example, Held, D., Models of Democracy (Cambridge, Polity Press, 1987).

15. Rousseau, J. J., The Social Contract (Harmondsworth, Penguin, 1968).

16. Mill, J. S., 'Considerations on Representative Government' in Action, H. B. (ed.), Utilitarianism, Liberty and Representative Government (London, Dent and Sons, 1951). 
theories of political theories such as MacPherson ${ }^{17}$ and Pateman ${ }^{18}$. The following Table summarises its main characteristics.

\section{Table 1. The Moral Model of Democracy}

Core Principles:

Democracy is an intrinsically justified form of social life constituted by the core value of political equality, it is the way of life in which individuals are able to realise their human capacities by participating in the life of their society. A democratic society is thus a society whose citizens enjoy equal opportunities for self-development, self-fulfilment and self-determination.

\section{Key Features:}

Democracy is a moral ideal and, as such, is never fully achieved. It requires continuously expanding opportunities for the direct participation of all citizens in public decision-making by bringing social, political, industrial and economic institutions under more genuine democratic control.

\section{Main Assumptions:}

Human beings are essentially political and social animals who fulfill themselves by sharing in the common life of their community. Since involvement in the life of the community is a necessary condition of individual development, all should participate in deliberations about the good of their society. Any distinction between rulers and ruled is a distinction in degree rather than in kind.

\section{Social Conditions:}

Democracy can only flourish in a society in which there is a knowledgeable and informed citizenry capable of participating in public decision-making and political debate on equal terms. It thus requires a society in which bureaucratic control over public life is minimal and in which decision-making is not treated as a professional expertise.

In this model, democracy is 'moral' in two senses. First, it is itself a moral way of life intrinsically constituted through fundamental human values. Democracy is thus not just a political system but a political expression of the values of self-fulfillment, self-determination and equality - values constitutive of the kind of society in which autonomous individuals can fulfill themselves by freely and equally determining the public good. Second, democracy is 'moral' in the sense that it prescribes the moral principles to which any society which claims to be democratic should conform. At such, it provides a moral basis for evaluating the social relationships, political institutions and cultural practices of any society that seeks to give expression to democratic values and ideals.

17. MacPherson, C. B., Democratic Theory: Essays in Retrieval (Oxford, Clarendon Press, 1973).

18. Pateman, C., Participation and Democratic Theory (Cambridge, Cambridge University Press, 1980). 
The conceptions of democracy which fall under the second model of democracy -the market model- don not claim to be 'moral' in either of these senses. Indeed, on this model, which included 'elitist' that democracy is a moral ideal is rejected as unrealistic, impractical, misleading and illusory. This model can be represented diagrammatically as follows:

\section{Table 2. The Market Model of Democracy}

Core Principles:

Democracy is justified extrinsically as the political system which is most instrumentally effective in securing the core principle of individual liberty. By providing a method for selecting political leaders which curtails an excess or abuse of political power, it helps to protect the freedom of individuals to pursue their private interests with minimal state interference.

\section{Key Features:}

Democracy is a value-neutral descriptive concept and its achievement is synonymous with certain empirical conditions. These include: regular elections, universal sufferage, the existence of rival political parties, a representative system of government, a centralised political leadership, a free press and an independent judiciary.

\section{Main Assumptions:}

Human beings are primarily private individuals who form social relationships in order to satisfy their own personal needs. They thus have no obligation to participate in political decision making and most ordinary people have no desire to do so. A rigid distinction is, therefore, made between an active elite political leadership and the passive majority of ordinary citizens.

\section{Social Conditions:}

Democracy flourishes in an individualistic society with a competitive market economy, minimal state intervention, a politically passive citizenry and a strong active political leadership guided by liberal principles and circumscribed by the rule of law.

What unites the different views of democracy incorporated in this market 'model' is their claim to offer a realistic understanding of democracy based on detailed empirical studies of how modern democratic societies actually work. What these studies claim to show is that the essence of democracy is not its allegiance to a moral ideal but its method of selecting between competing political elites for the right to exercise power. What these studies also claim to show is that most of the population of modern western democracies do not possess the knowledge or expertise that positive participation in political

19. Schumpeter, J., Capitalism, Socialism and Democracy (London, Allen and Unwin, 1976).

20. Dahl, R. A., A Preface to Economic Democracy (Cambridge, Polity Press, 1985).

21. Hayek, F. A., The Road to Serfdom (London, Routledge and Kegan Paul, 1976). 
decision-making requires. Democratic freedom is thus not the positive freedom to participate in political decision-making but the negative freedom to pursue one's private interests with the minimum of state cocrcion or control.

The fact that these two models of democracy have been presented as two isolated and independent models should obscure the extent to which they may, in reality, merge and overlap. Attention has been drawn to them only because they allow the formulation of some basic questions about what education for citizenship involves. What different ways is the notion of 'education for citizenship' understood in 'market' and 'moral' democracy? What are the curriculum and pedagogical implications of such differences? What, in a 'moral' and in a 'market' democracy, would education for citizenship actually involve?

Since, in a 'moral' democracy, the status of citizenship is only acquired through exercising the rights and duties of citizenship, citizenship means participating positively in a collective effort to reshape society in ways that will preserve the existing rights of citizens, enhance the possibilities for their practical realisation and develop new ways of making them more widely available. Clearly, citizens can only participate in this process if they are not so economically or socially deprived that their civil and political rights cannot be adequately exercised or enjoyed. This means that, in a 'moral' democracy, the state has some obligation to redistribute the wealth of society in a more egalitarian way than a free market economy would naturally allow. Hence, the social rights embedded in the institutions of the Welfare State are essential to minimise those social and economic inequalities which are incompatible with the civil and political equality that positive participation requires.

Although in a 'moral' democracy the maintenance of certain political and welfare institutions is necessary, it is not in itself sufficient. For citizenship to flourish, there must always be a critical tension between the ideals and values in terms of which the rights and duties of citizenship are defined and the dominant institutions which make provision for their practical enactment and realisation. It follows from this that 'eduction for citizenship' presupposes a critical understanding of the limitations of its own contemporary institutional definition. It also follows that an education for citizenship requires a specific political education which wil bring pupils to an historical consciousness of how present citizenship rights were achieved, how they became embedded in the legal, political and social institutions of the modern democratic state and how these institutions may now be functioning in ways which preserve, rather than prevent, the kind of inequalities and injustices they were originally established to eliminate. But, in addition, 'education for citizenship' will also require a 'general education' to meet the needs of citizens engaged in the common life of the community. Feinberg defined 'general education' as:

'...those forms of instruction primarily intended to further social participation as a member of the public through the development of interpretive understanding and social skills... It is that component of education that prepares students for a common life... General education, as education for participation in a public, ideally implies a community of equals, active partners engaged in a process of self-formation...22.

22. Feinberg, W., Understanding Education (Cambridge, Cambridge University Press, 1983), p. 228. 
In a moral democracy, the task of cultivating in pupils the knowledges, skills and attitudes necessary for this kind of public participation is the only way of providing an education which enables them to fulfil their status as citizens. It requires a curriculum which fosters those forms of critical and explanatory knowledge which allow pupils to reappraise existing social norms and reflect critically on the dominant social, political and economic institutions of contemporary society. Pedagogically, it requires participatory rather than instructional teaching methods in order to cultivate the skills and attitudes which democratic deliberation and participation require ${ }^{23}$.

What conception of citizenship is endemic to a democracy in which homo economicus takes preference over homo politicus and in which the notion of the market is assigned a central place? In a 'market' democracy, citizenship is invariably interpreted in ways which emphasise responsibilities rather than rights and thus is closely associated with law abiding behaviour, service to the community and national loyalty. In such a democracy, civil rights - particularly those associated with individual liberty and property ownership- tend to have an elevated status and the egalitarian thrust of social citizenship is rejected on the grounds that it creates precisely the kind of state-dependency and second class citizenship it originally promised to eliminate. From this perspective, citizenship is extended, not by the extension of social rights, but by creating a 'property owning democracy'. Only the expansion of 'popular capitalism' can free citizens from the stigma of social security and their reliance on the bureaucracies of the Welfare State ${ }^{24}$.

The kind of 'Education for Citizenship' appropriate in such a society will be very different from that which a moral democracy requires ${ }^{25}$. For example, since political apathy and ignorance are endemic in a market democracy 'education for citizenship' will have a marginal status in the curriculum corresponding to the marginal status of politics in the lives of individuals. For the most part, political education would combine an uncritical knowledge of how the institutions of government work with passive socialisation into the status quo. Since a market democracy prizes factual knowledge and vocational skills over social awarensess or critical reflection, the political role of 'general education' would not be seriously entertained. Those curriculum subjects which provoke open discussion about the processes and institutions of the modern democratic state subjects such as social studies and economics- will be systematically neglected and the role of subjects such as history and literature in preparing pupils to participate in the social life of their community will be minimised. In a modern market democracy 'education for citizenship' must not only depoliticize general education; it; must also depoliticize the concept of citizenship itself ${ }^{26}$.

Which of these two conceptions of 'education for citizenship' are currently being endorsed? To answer this question it is necessary to understand the historical traditions of English education in which contemporary understanding of education for citizenship

23. For a detailed discussion of the role of education in a moral democracy: see Gutmann, Amy, Democratic Education (Princeton, Princeton, Princeton University Press, 1987).

24. Hayek, See, op. cit., pp. 42-44.

25. For a detailed philosophical analysis and critique of education in a market democracy: see Tarrant, J. M., Democracy and Education (Gower Publishing Co., 1989).

26. Feinberg, op. cit., p. 231. 
is unavoidably embedded. And, to do this, it is necessary to connect contemporary questions about citizenship and education to the political, contexts and structures out of which have they emerged.

\section{CITIZENSHIP AND ENGLiSh POLITICAL AND EdUCATIONAL TRADITIONS}

The 19th century climate in which England developed its state schooling system and its modern political traditions, was one of immense social change and economic growth. During this period England became urbanised, suburbanised, secularised and partially democratised. Between 1861 and 1901 income per head of population more than doubled. Britain led the world in finance, trade and industry. It was, 'the forge of the world, the world's carrier, the world's shipbuilder, the world's banker, the world's workshop the world's clearing house, the world's entrepot ${ }^{27}$. These economic factors meant that England was a liberal, market dominated society, long before it became democratic. Political rights, in the limited sense of extending the franchise, came extremely slowly during the 19th century and were not fully completed until 1948. England, and the United Kingdom, did not have a major political event like the French or American revolutions which forced onto the public agenda a statement of the rights and duties of a citizen. There was (and still is) no equivalent of the American Declaration of Independence and no written constitution.

Between 1832 and 1948 the electorate was gradually extended first across class barriers and then across gender barriers. Each new group that entered the formal political arena had to do so on existing terms. This resulted in a peculiarly British view of 'the public' as 'all those people whom the state and its Establishment wish to address or acknowledge as their own' ${ }^{28}$. In English usage the public often means 'polite society' and raises issues about the membership of 'respectable, polite and responsible' groups. This usage can be seen in the label 'Public Schools' (those for the children of the wealthy) and 'public libraries' which were for the respectable and literate classes. The judgement about whether or not individuals are members of 'the polite, responsible, or respectable' is made by 'one's betters'. Until 1884 it excluded the entire working class and women; until 1918 it still excluded the bottom half of the working class. In contemporary debate it probably still excludes the poor, trade unions, and various minority groups. This view of the 'public' is encapsulated in Baroness Thatcher's famous phrase 'are they one of us?'.

All of this has important implications for the notion of citizenship. The slow and subtle move from an aristocratic society to a formally modern democratic society meant that the old characteristics continued. In particular, a hereditary royal family with (until recently) symbolic power and popular support; an unelected second chamber -the House of Lords; and a secretive and hierarchical culture which has only partly accepted the idea that democracy should influence the whole range of public life and the operation of pu-

27. Connell, W. F., The Educational Thought and Influence of Matthew Arnold (Routledge \& Kegan Paul, 1950), p. 3.

28. Johnson (1985), op. cit., pp. 232-234. 
blic institutions. Given this historical background it is easy to see how the 'market' model of democracy fitted English society like a hand in a glove, and how the impact of democracy could be contained and limited to regular elections for competing groups of politicians.

These political traditions were made even more important by the way in which the state educational system has developed. Until the mid-19th century, England lacked a strong motivating drive to take an interest in education. Unlike America or France it had not had a revolution which required a serious public debate about the role of citizenship in the modern state. Uniquely, it had industrialised without a state run education system. During the 19th century it exported rather than imported people and therefore lacked the American problem of turning immigrants into citizens. The complex religious issues which arose in, for example, Scotland and the Netherlands, did not produce, in England, the Calvinist pressure for literacy; and it seemed as if the religious issue could be resolved by doing nothing for as long as possible ${ }^{29}$.

All this meant that England was, by international comparisons, exceptionally slow to develop a national system of schooling. When it was eventually established, in the second half of the 19th century, the schools were not for the children of citizens, with full political rights, but largely for children of the 'lower orders', many of whom still did not have a formal vote. By 1850 when Holland, Switzerland, Germany, and the northern states of America, virtually had universal education, England had barely half the age group in school. In the same way, when England instituted state secondary schooling in 1902 it was ' 100 years after Napoleon created the lycees and almost as long since the U.S.A. and the German states created public elementary schools ${ }^{30}$. In the same way higher education was only gradually extended and still remains the preserve of a minority. this failure to see the connection between political advance and educational provision effectively inhibited the development of an 'educated public' which is so vital to the construction of a democratic citizenry and replaced it with the notion of a 'public' which is exclusive, selective and respectable.

These tendencies towards preserving aristocratic and feudal elements in a supposedly democratic society have been supported and increased by key characteristics of the English educational system. For example, there has never been an English 'system' of education as such. Rather it has evolved in a fragmented, voluntarianist and uncoordinated manner. Educational reform, like the political changes which often precede it, has always, been preoccupied with the partial and the specific: to limit and constrain change to the minimum required and to do it as cheaply as possible. Higher elementary schools, grammar schools, comprehensive schools and the polytechnics have all, in their time, been agents of modernisation and democratic advance. But they have had to be assimilated into a structural framework in which the 19th century citadels of exclusion and exclusiveness -public schools and the ancient universities- remained hardly touched by democratic and egalitarian ideals. State power has rarely been used to shift the debate

29. Wardle, D. English Popular Education 1780-1795 (Cambridge University Press, 1976), Chapter Two.

30. Green, A. 'The peculiarities of English education' in Education Limited: Schooling, Training and the New Right in England since 1979 (Unwin Hyman, 1991), p. 8. 
onto the complex issues of citizenship and education. Instead, a great suspicion of the state, has allowed voluntarianism to flourish through the 19th century religious societies, the endowed school movement, the public schools and the grammar schools. These have been the socially and politically acceptable educational mechanisms and institutional frameworks through which structural inequalities could continue to flourish, be reinforced and be legitimated. The explicit 19th century assumption that social class should determine the type and quality of education that children are given, has in the 20th century, been replaced by the assumption that innate individual differences in children's ability should be the mechanism for making distinctions between and within schools. In the twentieth century 'meritocracy' has replaced aristocracy as the new agency of exclusiveness and exclusion.

A second, and related, characteristic of the English education is its obsession with differentiating, grading, sorting, classifying, and testing pupils from an early age. In Turner's phrase it is a 'sponsored' system rather than a 'contest' system ${ }^{31}$. This means that the most deserving rather than the most able win the prizes; that talent has to be identified early; that the criteria for defining talent are beyond serious public debate; and, perhaps most importantly, that too much talent is a sure sign of falling standards. It also means that the questions about how citizens should be educated is always subordinated to questions about the sort of education appropriate for different sorts of people. This leads, quite easily, to different sorts of schools, curricula and pedagogy for different groups of people.

Just as the middle class, the upper working class, women, and the lower working class had to wait to get the vote, so their children had to wait patiently to be invited into the great English educational institutions of the 6th form and the university. Incredibley, until the mid-1960's, the vast majority of children were publicly excluded, at the age of 11 , from most opportunities to pursue higher education and upward mobility. When in 1965 a Labour government tentatively proposed to end this educational apartheid the Prime Minister (Harold Wilson) had to say that the real aim was 'a grammar school education for all'. As E. P. Thompson has shown, although the excluded groups did not always follow the paths set out for them, the fact that the paths were at least in theory available, is an important aspect of English culture and history ${ }^{32}$.

A third important characteristic of the English education system is the critical and continuing role played by elite schools and institutions, particularly Public Schools and the ancient universities. As Stone argues, the "nineteenth-century English Public School was (and still is) a highly successful device for the preservation in an industrialised society of aristocratic values, institutions and distribution of power and wealth ${ }^{33}$. These schools were, and are, the educational equivalent of the rotten boroughs of the 19th century where privilege and status can be bought on the open market. In England, unlike many other societies where the main purpose of private schools... is to satisfy minority

31. Turner, R. H., 'Modes of social ascent through education: sponsored and contest mobility' in Halsey, A. H.; Floud, J. \& Anderson, C. A. (eds.), Education, Economy and Society (Free Press of Glencoe, 1961), pp. 121-139.

32. Thompson, E. P., The Making of the English Working Class (Penguin, 1968).

33. Stone, L., 'Literacy and education in England' 1640-1990', Past and Present, 42, pp. 69139. Quotation form p. 73. 
and mainly religious groups', they 'provide an intensive education for the children of the upper middle class' and give 'far better access to positions of influence, power and affluence than do other schools ${ }^{34}$. Not only do such schools get various economic and taxation advantages, they also subvert the state system by generally ensuring that their criteria and standards become the criteria and standards by which state schools are judged.

Given these political and educational traditions, it is easy to understand why England has no tradition of taking citizenship seriously. It has separate educational institutions for leaders and led, and often separate curriculum, pedagogy and assessment for each of these groups. Its political traditions are based on an extremely limited model of democracy and its view of the 'public' is exclusive and excluding and quite different from the 'educated public' that is a precondition for a fully democratic society. In this situation it is hardly surprising that England has no tradition of asking the right questions about citizenship at the level of serious political discussion and that vacuous rhetoric continues to replace the hard task of re-examining educational provision in the light of the requirements of a fully democratic society. Nor is it surprising that education and schooling in England, far from reducing the impediments to citizenship, have magnified, legitimated and fossilised them.

\section{NEW RIGHT'S SOLUTIONS}

Between 1979 and 1993 the Conservatives won four general elections and their educational policy was increasingly influenced by the ideas and rhetorics of the New Right: allowing the 'market' to be the key mechanism for distributing educational resources and making market forces the levers of social and cultural change. In doing this, the New Right achieved four important successes. Firstly, they captured and took over an educational vocabulary of the 'best words ${ }^{35}$. These included excellence, quality, core subjects, traditional, discipline, standards, examinations, parents, freedom, market, choice, and local autonomy. These could be counter-posed with 'bad' words such as equality, experts, expertise, educationalists, militant teachers, loony left councils, ill-discipline, falling standards, progressive education, anti-racism, anti-sexism, local bureaucrats, political indoctrination and many more. What Ball calls the 'discourse of derision' uses these 'best' and 'bad' words in a repetitive, but politically effective, manner ${ }^{36}$.

Secondly, by a use of rhetoric, evidence, and story-telling they reconstructed a golden past for education. In that golden age enormous opportunities existed for the working class (via grammar schools and especially the 6th form); educational standards were high because everyone could read, write and do their sums; schools were centres of discipline and order; and teachers knew how to teach through whole class formal pedagogy.

34. Green (1991), op. cit., pp. 14-15.

35. Knight, C., The Making of Tory Education Policy in Post-War Britain 1950-1986 (Falmer, 1990), p. 91.

36. Ball, S. T., Politics and Policy Making in Education (Routledge, 1990). Chapter Two. 
Teachers led the children forward to real learning. The curriculum was made up of 'proper' subjects (like Latin) and assessment really tested children through formal examinations with pencil and paper. Selection and differentiation ensured that children were taught in a way which reflected their abilities and needs and there was no nonsense about mixed ability teaching. The New Right established the view that all new developments had to be judged and evaluated against this traditional golden age. If changes did not measure up they were discounted. Throught these techniques and processes the New Right constructed an alternative view of the past to that presented by what it called «the educational establishment's» view.

Thirdly, the New Right created by hard work, imaginative use of language and the use of the media, a new, populist form of discourse based on pamphlets, the 'findings' of its think-tanks, and common-sense language. This discourse was not directed, at educational experts or teachers, but at parents and voters. Finally, during the 1980s and 1990s, when the Conservative Government had to face the awkward question of what to do about education, the New Right was ready with ideas and proposals which could become policy almost over-night. What had, in the 1960's and 1970's, seemed to be bizarre, poorly thought out policies, that appeared to be more at home in the saloon bars of Conservatives clubs, were now to be translated into government policy. During the 1980's, New Right ideas and prejudices became a 'counter-reality' to the complexities of what was actually happening (and what had happened) in schools, and provided an essential resource to the years of Conservative rule.

The Conservative party in government has, with considerable help from the New Right, altered the general discourse about education so that it reflects their vocabularies, concerns, claims and aspirations. Through acts of parliament they have made substantial changes to the policy framework within which education takes place; and they have altered in radical ways the consensues about education which they inherited. They have moved the debate about education away from serious public debate about its political and cultural role, and replaced deliberation, evidence, argument and contestation with ideological assertion and unexamined political prejudice. They have ensured that educational policy has been shifted towards creating their vision of the good society and, through a combination of managerialism, centralisation, and bureaucracy they have asserted the importance of authority and the strong state. In short, through devolution, opting-out and market forces they have reasserted the critical role of the neo-liberal intellectual tradition in which the notion of citizenship is of minimal significance.

Educational policy making, is, of course, a lot more complex than politicians sometimes think and its outcomes and unintended consequences are often more important than its officially stated aims. As Bowe and Ball suggest there are at least three arenas in the process of policy formation ${ }^{37}$. Firstly, there is the 'context of influence' where 'public policy is normally initiated" ${ }^{38}$. Particularly important here are the various thinktanks, and official and unofficial advisers to politicians, as well as senior individual civil servants. Secondly, there is the 'context of policy text production'. Bowe and Ball give

37. Bowe, R.; Ball, S. \& Gold, A., Reforming Education and Changing Schools (Routledge), pp. 19-23.

38. ibid., p. 19. 
here the examples of acts of parliament and official commentaries on these texts. They further suggest that these texts will often be internally contradictory and will often be produced as a result of 'struggle and compromise" ${ }^{39}$. Thirdly, there is 'the context of practice'. This refers to yet another potential arena for conflict, contestation and compromise: the particular schools, educational institutions and local authorities where policy is enacted. As Rizvi and Kemmis put it, "people who have to participate in (or "implement') a programme will interpret it in their own terms, in relation to their own understanding, desires, values and purposes... In short, all aspects of a programme may be contested by those involved in a programme, moreover a programme is formed and reformed throughout its life through a process of contestation, 40 .

What this means is that any official policy for education for citizenship will not interpret itself, and the way in which schools make sense of such a policy will be conditioned by discussions conducted between teachers on the basis of their own educational values and in relationship to the structures of meaning and understanding within which they work. But since 'citizenship' and 'democracy' are both essentially-constested concepts, such discussions will always be marked by contestation, and conflict about the meaning of the concepts in terms of which the discussion proceeds. Should such discussions adopt the prevailing 'market' concepts of citizenship and democracy? Or should they involve critically examining and revising those concepts in the light of some fundamental educational values and democratic ideals? Is 'education for citizenship' itself a political right of all future citizens in a democracy, and, if so, how is this entitlement to be met? It is precisely because citizenship is an essentially contested concept that such questions cannot be settled prior to questions about how any education for citizenship should be implemented. To force schools to 'deliver education for citizenship' on the basis of some prior stipulative definition of 'what citizenship is' is merely to deprive citizenship of its indispensable political dimension.

In the conclusion to his recent book on citizenship, Derek Heater wrote:

\begin{abstract}
'Disagreement is rife about what citizenship means and consequently about the educational processes most appropate to support citizenly status, role and qualities. This cannot be a satisfactory conclusion. At best, it leads politicians and educationalists into semantic confusion; at worst, young citizens are beining fobbed off with only a portion of that whole citizenship which should in fact lay at the heart of their life as social beings ${ }^{41}$.
\end{abstract}

Schools can only be confident that their pupils are not being 'fobbed off' in this way, if they are encouraged to provide the curriculum and teaching space in which the essential contestability of citizenship can be protected from a political climate which increasingly requires such space to be closed. The only kind of civic education which can prepare citizens for life in a fully democratic society is one which acknowledge both that the meaning of citizenship is perennially the subject of contestation, and that it is through this process of contestation that the relationship between the citizen and the state

39. ibid., p. 20.

40. Quoted in Bowe, R.; Ball, S. \& Gold, A., op. cit., p. 22.

41. Heater, D., Citizenship: the Civic Ideal in World History, Politics and Education (Longman 1990), p. 310. 
is being continuously re-defined. In this process, the political and educational agenda of the New Right will, like any other, have to be confronted, argued against, and assessed. Indeed, in educational institutions committed to developing an education for citizenship which speaks to a fully democratic society, the conception of citizenship, which the New Right seeks to impose, will not be allowed to define and constrain what is to be taught and learned but will itself be treated as a legitimate subject for criticial discussion and open debate. 